\title{
A JOURNAL'S JOURNEY ACROSS TIME AND SPACE: THE \\ IMPORTANCE OF ILHA DO DESTERRO WITHIN LOCAL, NATIONAL, AND TRANSNATIONAL CONTEXTS
}

\author{
Renata Wasserman* \\ Wayne State University \\ Anelise Reich Corseuil ${ }^{* *}$ \\ Universidade Federal de Santa Catarina \\ Magali Sperling Beck*** \\ Universidade Federal de Santa Catarina \\ Mailce Borges Mota***** \\ Universidade Federal de Santa Catarina \\ Rosane Silveira ${ }^{* * * * * *}$ \\ Universidade Federal de Santa Catarina
}

In 2017, thirty seven years after it began publication, Ilha do Desterro: a Journal of English Language, Literatures and Cultural Studies celebrates its 70th volumes. Ilha do Desterro is published by the Graduate Program in English at the Universidade Federal de Santa Catarina and EDUFSC, Editora da Universidade Federal de Santa Catarina. Its journey along time and space represents not only the process of consolidation of an academic journal whose first publication was back in 1979 as "A Journal of Criticism Centering Around the Invisible Generation", but also the mapping of a culturally marked space that shows the value of transnational partnership among scholars in a connected world. Along time, the journal has had a double mission: to think critically about cultural production within the Anglophone world, and to offer to its readers state-of-the-art bilingual research in English Language, Literatures in English, and Cultural Studies originating in different local, national and transnational contexts, collecting and making available work by scholars from all over Brazil and worldwide. Ilha do Desterro is available in a range of international electronic databases, such as SCOPUS, SciELO, the MLA International Bibliography, SEER - Sistema Eletrônico de Editoração de Revistas, Sumários de Revistas Brasileiras, DOAJ - Directory of Open Access Journals, Livre! PKP - Public Knowledge Project, OJS - Open Journal Systems, Latindex - Sistema Regional de Información en Línea para Revistas Científicas de América Latina, el Caribe, España y Portugal, and Ulrichsweb - The Global Source for Periodicals, among others.

${ }^{*}$ Anelise R. Corseuil is Professor of Literatures in English and Film Studies in the Graduate Program in English at UFSC. She holds a PhD in Literatures in English from Wayne State University and she is currently the editor-in-chief of tha do Desterro Journt.

***Professora do Departamento de Língua e Literatura Estrangeiras da UFSC. Editora-Assistente dos periódicos Illa do Desterro e Revista Estudos Anglo-Americanos. Desenvolve pesquisa em literaturas de língua inglesa na contemporaneidade, enfatizando narrativas de viagem e deslocamentos geográficos e culturais.

****Mailce Borges Mota is a member of the faculty in the Department of Foreign Languages and Literature at the Federal University of Santa Catarina. She is the director of the Language and Cognitive Processe Lab and a CNPq fellow. Her research focuses on the relationship between memory systems and language processing.

*****Faculty member of the Departament of Foreign Language and Literature and the English Graduate Program of the Universidade de Santa Catarina - Brazil CNPq researcher. Her research interests include the development of L2 speech, with a focus on phonetics, phonology and pronunciation teaching. E-mail: rosanesilveira@hotmail.com 
In this concise description of Ilha's course along time and space, we will also trace some major changes in the Journal's editorial line. The first issue, edited by Dilvo I. Ristoff together with Nona and Hugh Fox, had a handwritten front cover and a statement by Hugh Fox, which was, above all, an invitation for readers to keep up with the fresh spirit the journal would represent rather than the mausoleums of literature, and that, of course, included the reading of a more recent constellation of American poets. Having begun its publication with literary themes, always within an Anglophone perspective, it was not until its 3rd volume that Ilha do Desterro started to publish articles related to language and linguistics. Conceived as a locus of intellectual and academic work on literature and culture, the journal's initial approach to language studies was interdisciplinary: the three papers published in 1982 (vol. 3, n. 7) addressing themes in language and linguistics did so in dialog with literature. In her paper, Rosa Konder, author of the Longman English Dictionary for Portuguese Speakers, discusses theoretical and methodological issues related to the teaching of literature in a language teacher education program: how much literature should a language school teacher know? How should literary texts be dealt with in low proficiency classes? How could language and literature be integrated in the curriculum? She addresses these questions by drawing on H.G. Widdowson's and R. Pearce's ideas. Caldas (later Caldas-Coulthard), in turn, analyses tense in simple (children's stories) and complex (literary) narratives. Finally, Scott applies principles of Halliday's view of language to an analysis of Margaret Atwood's Surfacing.

This conversation between language and literature was still seen in volume 4 (n. 9, 1983), but the following issue (vol 5, n. 11, 1984) is a landmark for language studies in Ilha do Desterro. In her Editor's Note, Caldas-Coulthard states: "From now on, it is our intention to share critical thought not only on Literature, but also on Linguistics, Language, and Language Teaching" (Caldas-Coulthard, 1984, p. 7). To implement the new editorial policy, a decision was made to publish two thematic issues per year, each edited by invited experts. The first thematic issue of Ilha do Desterro dedicated to language studies was n. 11, published in 1984. The issue put together a collection of papers by renowned researchers in the area of Discourse Analysis.

In 1994, Anelise R. Corseuil, the new Editor-in-Chief, expands the scope of Ilha by including Cultural Studies as its newest area of interest. In 2004, Professor Renata Wasserman, a specialist in the area of Comparative Literature, mainly Anglophone and Brazilian Literatures, was invited to be the journal's International Editor. In the same year, the editorial board was expanded to include new members. Along this process of internationalization, in 2007, Ilha's issues became available on line. Pursuing its politics of expansion, in 2007, Itha also became available as a free access journal at OJS and, since 2012, it has been included in major databases such as SCOPUS and SciELO. Nowadays, Ilha is classified as an A1 journal under QUALIS CAPES.

In 2015, the journal expanded its editorial line by starting to publish three issues per year instead of two and, in 2016, by including non-thematic issues 
dedicated, in alternate years, to the areas of language and literature, along with the thematic issues. Thus, beginning in 2015, Ilha do Desterro has complied with newer editorial demands to seek a more intensive chronogram of publication and, as a consequence, broader visibility worldwide by instituting a shorter interval between issues. One of the most positive consequences of this change is that it allows the publication of the results of more recent research work. Volume 68, number 1, whose title is L2 Teacher Education: Bridging the Complexities of Teaching and the Learning of Teaching, organized by Professors Adriana Kuerten Dellagnelo and Karen E. Johnson (2015), was the first volume in Ilha's new format of publishing three volumes per year. Moreover, in 2016, a new team of editors, peer reviewers and staff inaugurated the editorial mission of also publishing non-thematic numbers. Along with Renata Wasserman and Anelise Reich Corseuil, international editor and chief-editor, respectively, Magali Sperling Beck, Mailce Borges Mota and Rosane Silveira became the journal's new associate editors. Number 69.1, The Multiple Facets of Language (2016), organized by Rosane Silveira, was the first non-thematic issue of Ilha do Desterro. We note, with pleasure, the high number of submissions received for the non-thematic numbers of Iha. For Volume 70.1, a non-thematic issue under the organization of Magali Sperling Beck (2017), more than 40 manuscripts were submitted.

As per our thematic issues, our Editorial Committees have assisted us along these years in the selection of topics that best represent the research work and teaching interests of professors, researchers and graduate students in the areas of English Language and Linguistics, Literature and Cultural Studies, thus helping us to achieve this landmark: the completion of our 70th published volume.

In the area of Language, the journal has covered a wide spectrum of research work, encompassing issues on Translation Studies, Text Analysis, Writing, Interfaces between Literature and the teaching of a Foreign Language; Phonology; Second Language Acquisition; Critical Reading and Psycholinguistics; Neurosciences and Reading, Language and Cognition, among others. On the topics of Literary and Cultural Studies, Ilha has published articles on Anglophone expression by itself, and in comparison to its counterparts in the Lusophone world, as well as on Adaptation Studies, Literary Theory, and Comparative Literature. A short history of our thematic issues may illustrate its importance within an academic context.

Our first thematic issue, organized by Malcolm Coulthard, was on Discourse Analysis. The issue was at the vanguard of an area of study in its beginnings in Brazil and would establish PPGI/UFSC as a reference in Discourse Analysis research, with the successful advising of innumerous MA theses and $\mathrm{PhD}$ dissertations in the area. Our thematic issues on Language and Linguistics, such as those on Discourse Analysis; Textual Analysis; Translation Studies, Semantics; Systemic Functional Linguistics; Reading and Writing; L2 Learning; Multimodality; Corpus Linguistics, Cognitive Linguistics, Phonology, Language Acquisition and Critical Reading among others, were in accordance with new epistemological currents in the field of Linguistics. For instance, when we compare the thematic 
issues on Discourse Analysis, published in 1984, with the issue titled Expression, Identity and Society, organized by José Luiz Meurer, Keizo Nanri, Makoto Sasaki and Seiko Yasumoto (2006), we can observe a change of approach revealed in its transdisciplinary perspective. The comparison demonstrates academic developments in the various areas of study covered by Ilha and its association with national and international areas of critical debate.

Furthermore, the principles of interdisciplinarity and of multiple approaches to a theme have been preserved as a core element of the journal's policy throughout its trajectory. In some cases, it is possible to find various issues approaching the same theme from different conceptual frameworks and paradigms: for instance, reading and second language learning, two recurrent topics, have been treated from instructional, sociocultural, psycholinguistic, and neurocognitive perspectives. In the case of L2 learning, it is possible to find issues entirely dedicated to specific subfields such as L2 speech, phonological acquisition, the role of technology, and teacher education.

One topic that has kept open the dialog between language and literature is translation studies, as can be seen in this current issue edited by Michael Toolan and Lincoln Fernandes. The first thematic is sue devoted to translation was released in 1987 (issue 17) and edited by Walter Carlos Costa. The articles published in issue 17 focus mainly on the translation of literary texts. On the other hand, issue 28, published in 1992 and organized by Malcolm Coulthard, presented a collection of articles discussing translation studies in connection with Sociolinguistics; Pragmatics; Discourse Analysis; and Phonology as well.

Emphasis must be placed on the fact that, most often, thematic issues on language and literary studies have been co-edited by a Brazilian researcher and at least one international leading investigator in the area of the theme. In line with Ilha do Desterro's policy, papers that report on analyses of linguistic or literary phenomena necessarily focus on the English language.

In relation to the issues on Literary and Cultural Studies, all themes are clearly inserted within transnational contexts. The thematic issue Women Writers, from 1984, organized by Susana Funck, points at a research area that has involved the education of new professionals whose perspective on canonical works and whose awareness of a politics of inclusion/exclusion have definitely created paradigmatic changes. In the same vein, publications on Shakespearian Studies, organized by José Roberto O'Shea et al (1999; 2010), have opened up new venues of debate about the role of canonic texts as well as newer perspectives on them. Along those lines, one can also include Ilha's thematic issues on other significant literary figures, such as James Joyce and Virginia Woolf.

Ilha has also welcomed thematic issues on the cultural productions of different geopolitical Anglophone spaces, also from a comparative perspective, such as Canada, South Africa, Australia, among others. The issues Canadian Studies (1994), organized by Sigrid Renaux, Poetics and Other Discourses of Resistance in Canada (2009), organized by Susan Rudy and Maria Lúcia Milléo Martins, South Africa: Literature and Media (2011), organized by José Gatti, and New Cultural 
Landscapes in Australian Literature and Film (2015), organized by Eduardo Marks de Marques and Anelise R. Corseuil, demonstrate the relevance of Ilha as a transnational forum. This same characteristic is present as well in thematic issues that address broader geopolitical locations, such as Literaturas de Lingua Inglesa: Mediações Globais/ Literatures in English: Global Mediation (2008), organized by Sônia Torres and Eloína P. dos Santos, which covers discussions on the role of artists and writers in the face of globalization, and Crossing North and South: Re-visiting the Americas (2014), organized by Magali Sperling Beck and Rubelise da Cunha, which encompasses the area of Inter-American Studies.

Some specific volumes published by Itha are more markedly theoretical. Here we can include, Trends in Contemporary American Criticism/ Tendências da Crítica Norte-Americana Contemporânea (1989), organized by Sérgio L.P. Bellei, Postcolonial Cultures in Contact: Bras(z)il/ Canada(á) (2001), also organized by Sérgio L. P. Bellei together with Neil Besner, Diversity and/ or Difference? Critical Perspectives (2005), organized by Eliana Ávila e Liane Schneider, and On Foreign Land: Ideologies and Travel Discourse (2009), organized by Sandra Regina Goulart Almeida and Renata Wasserman. Not only post-colonial and post-structuralist criticism underlie these publications and others, but these thematic issues also demonstrate a recurrent concern with debates on identity, difference, and the politics of representation. In the issue On Foreign Land (cited above), for example, one notes a preoccupation in questioning the definitions of self and other, particularly in the context of travel writing.

From its beginnings, Ilha has always been attuned to what is new in literary and language studies. Therefore, it comes as no surprise that Ilha is also interested in publishing works that cross disciplinary boundaries. It was with this impulse that Ilha's Editorial Board decided, in 1994, to include in its title the area of Cultural Studies, an area that had already been explored in the journal. Taking this field of investigation into consideration, we would like to highlight those issues that offer a revision of approaches to, and perspectives on, literature, which were mostly made possible by Cultural Studies. Here we can include Ilha's issue Gender Studies and Feminist Perspectives (2002), organized by Sandra Regina Goulart Almeida, a volume that can be seen in relation to the issue Women Writers, from 1985.

Cultural Studies established a conversation among the cultural production of different nationalities, cultures, aesthetics, and disciplines making visible the relations between cultural productions and their contexts, economic, disciplinary, or aesthetic, within a globalized world that invests culture itself with newer and transgressive meanings. The same transdisciplinary tendency is seen in filmic production in which the filmic text is more and more associated with its context of production and reception. It is within this transdisciplinary context that Ilha published issues like Film, Literature, and History (1997) and Film Beyond Boundaries (2006), both organized by Anelise R. Courseuil, as well as New Perspectives to History Through Literature (2010), organized by Giséle Manganelli Fernandes and Norma Wimmer, and Body, Literature, Arts and Media (2015), 
To our first editors and founders, to our readers and colleagues, as well as members of our Editorial Board and those belonging to our technical support team, which makes Ilha available to all, our recognition for their vision and support. We want to move on in our mission of circulating the most advanced research work in the areas covered by our journal and to keep intact the avantgardist spirit that moved Hugh Fox in his first publication of Ilha do Desterro: to provide visibility to the work of those who are the antennae of the world. What moves us all, after all, is poetry.

\section{Published volumes of Ilha do Desterro}

Ristoff, Dilvo, Fox, Hugh, and Nona Fox, eds. I lha do Desterro: A Journal of Criticism Centering Around the Invisible Generation 1 (Mar 1979): 01-42.

Ristoff, Dilvo, Hugh Fox, and Nona Fox, eds. Ilha do Desterro: Poesia Também é Literatura 2/3 (May 1979): 001-158.

Ristoff, Dilvo, ed. I lha do Desterro: An Underview of Contemporary North American Literature 4 (Dez 1979): 01-78.

Ristoff, Dilvo, ed. Ilha do Desterro 5 (May 1981): 01-91.

Ristoff, Dilvo, Paul Jenkins and John Derrick, eds. I tha do Desterro: AngloAmerican Literature 6 (Nov 1981): 07-90.

Ristoff, Dilvo, and Eliane Luz Bayer, eds. Ilha do Desterro 7 (Jul 1982): 001-119.

Ristoff, Dilvo, John Bruce Derrick, Eliane Luz Bayer, and Arnold Gordenstein, eds. Ilha do Desterro 8 (Dez 1982): 001-112.

Ristoff, Dilvo, John Bruce Derrick, Arnold Gordenstein, and Carmen Rosa Caldas, eds. Ilha do Desterro 9 (Jul 1983): 001-113.

Ristoff, Dilvo, John Bruce Derrick, Arnold Gordenstein, Eliane Luz Bayer, and Carmen Rosa Caldas, eds. Ilha do Desterro 10 (Dez 1983): 001-122.

Coulthard, Malcolm, ed. Ilha do Desterro: Discourse Analysis/ Análise do Discurso 11 (1 $1^{\text {st }}$ Sem 1984): 001-145.

Gordenstein, Arnold, and Walter Carlos Costa, eds. Ilha do Desterro: James Joyce 12 (2 $2^{\text {nd }}$ Sem 1984): 001-132.

Scott, Michael R., ed. Ilha do Desterro: Reading/ Leitura 13 (1 $1^{\text {st }}$ Sem 1985): 007105.

Funck, Susana Bornéo, ed. Ilha do Desterro: Women Writers/ Mulheres Escritoras 14 ( $2^{\text {nd }}$ Sem 1985): 001-121.

Gordenstein, Arnold, ed. Ilha do Desterro: American Literature and Culture 15/16 ( $\left.1^{\text {st }} / 2^{\text {nd }} S e m 1986\right): 001-225$.

Costa, Walter Carlos, ed. Ilha do Desterro: Translation/ Tradução $17\left(1^{\text {st }}\right.$ Sem 1987): 001-130.

Caldas, Carmen Rosa, ed. Ilha do Desterro: Narrative Studies / Estudos Narrativos 18 ( $2^{\text {nd }}$ Sem 1987): 001-132.

Scliar-Cabral, Leonor, ed. Ilha do Desterro: Psycholinguistics/ Psicolingüística 19 ( $1^{\text {st }}$ Sem 1988): 001-140. 
Lira, Solange A., and Paulino Vandresen, eds. Ilha do Desterro: Sociolinguistics/ Sociolingüística 20 ( $2^{\text {nd }}$ Sem 1988): 001-116.

Scliar-Cabral, Leonor, ed. Ilha do Desterro: Reading: Creative and Automatic Processes 21 ( $1^{\text {st }}$ Sem 1989): 001-113.

Bellei, Sérgio Luiz Prado, ed. Ilha do Desterro: Trends in Contemporary American Criticism/Tendências da Crítica Norte-Americana Contemporânea 22 ( $^{\text {nd }}$ Sem 1989): 01-98.

Ristoff, Dilvo, ed. Ilha do Desterro: American Literature of the 1930's 23 (1 $1^{\text {st }}$ Sem 1990): 001-156.

Pasold, Bernadete, ed. Ilha do Desterro: Virginia Woolf 24 (2 ${ }^{\text {nd }}$ Sem 1990): 001114.

Caldas-Coulthard, Carmen Rosa, Hilário I. Bohn and Susana Bornéo Funck, eds. Ilha do Desterro: Retrospective Issue / Retrospectiva 25/26 ( $1^{\text {st }} / 2^{\text {nd }}$ Sem 1991): 001-240.

Meurer, José Luiz, ed. Ilha do Desterro: Text Analysis/ Análise de Texto 27 ( $1^{\text {st }}$ Sem 1992): 009-188.

Coulthard, Malcolm, ed. Ilha do Desterro: Studies in Translation/ Estudos de Tradução 28 (2 $2^{\text {nd }}$ Sem 1992): 001-188.

Bamberg, Betty, and Dilvo Ristoff, eds. Ilha do Desterro: Writing 29 ( $1^{\text {st }}$ Sem 1993): 001-155.

O'Shea, José Roberto, ed. Ilha do Desterro: Literature of the South of the United States 30 ( $2^{\text {nd }}$ Sem 1993): 001-108.

Renaux, Sigrid, ed. Ilha do Desterro: Canadian Studies 31 (1 ${ }^{\text {st }}$ Sem 1994): 001-192.

Corseuil, Anelise R., ed. Ilha do Desterro: Film, Literature, and History 32 ( $1^{\text {st }}$ Sem 1997): 001-212.

Lörscher, Wolfang, ed. Ilha do Desterro: Translation Studies in Germany 33 (Jul/ Dez 1997): 001-122.

Rauen, Margarida Gandara, ed. Ilha do Desterro: English Renaissance Poetry and Drama 34 (Jan/Jun 1998): 001-136.

Baptista, Barbara O., and Mailce M. Fortkamp, eds. Ilha do Desterro: Cognitive Perspectives on the Acquisition/Learning of Second/ Foreign Languages 35 (Jul/ Dez 1998): 001-264.

O'Shea, José Roberto, ed. Ilha do Desterro: Accents Now Known: Shakespeare's Drama in Translation 36 (Jan/Jun 1999): 001-404.

Brandão, Izabel F. O., ed. Ilha do Desterro: The Challenge of Literature and Foreign Language Teaching and Learning 37 (Jul/Dez 1999): 001-154.

Tomitch, Lêda Maria Braga, ed. Ilha do Desterro: Critical Reading 38 (Jan/Jun 2000): 001-192.

Corseuil, Anelise R., ed. Ilha do Desterro 39 (Jul/Dez 2000): 001-195.

Besner, Neil, and Sérgio Bellei. Ilha do Desterro: Postcolonial Cultures in Contact: Bras(z)il/ Canada(á) 40 (Jan/Jun 2001): 001-159.

Gil, Glória, and Denise Prina Dutra, eds. Ilha do Desterro: Current Issues in the Teaching and Learning of Second/ Foreign Languages 41 (Jul/Dez 2001): 001280. 
Almeida, Sandra Regina Goulart, ed. Ilha do Desterro: Gender Studies and Feminist Perspectives 42 (Jan/Jun 2002): 001-380.

Scliar-Cabral, Leonor, ed. Ilha do Desterro: Unity and Diversity in Communication 43 (Jul/Dez 2002): 001-220.

Corseuil, Anelise R., ed. Ilha do Desterro: English Language and Linguistics Retrospective Issue 44 (Jan/Jun 2003):011-296.

Corseuil, Anelise R., ed. Ilha do Desterro: Literature Retrospective Issue 45 (Jul/ Dez 2003): 001-180.

Heberle, Viviane, and José L. Meurer, eds. Ilha do Desterro: Systemic Functional Linguistics in Action 46 (Jan/Jun 2004): 001-296.

Oliveira, Roberta Pires de, and Apóstolo T. Nicolacópulos, eds. Ilha do Desterro: Semantics: Lexicon, Grammar and Use 47 (Jul/Dez 2004): 001-268.

Ávila, Eliana, and Liane Schneider, eds. Ilha do Desterro: Diversity and/ or Difference? Critical Perspectives 48 (Jan/Jun 2005): 001-248.

O'Shea, José Roberto, Daniela Lapoli Guimarães and Stephan Arnolf Baumgärtel, eds. Ilha do Desterro: Mixed with Other Matter: Shakespeare's Drama Appropriated 49 (Jul/Dez 2005): 001-430.

Meurer, José L., Keizo Nanri, Makoto Sasaki and Seiko Yasumoto, eds. Ilha do Desterro: Expression, Identity and Society 50 (Jan/Jun 2006): 001-192.

Corseuil, Anelise R., ed. Ilha do Desterro: Film Beyond Boundaries 51 (Jul/Dez 2006): 001-368.

Rocha, Marco, ed. Ilha do Desterro: Corpus Linguistics 52 (Jan/Jun 2007): 001216.

Vieira, Josalba Ramalho, and Solange Coelho Vereza, eds. Ilha do Desterro: Metaphor in Language and Thought: Contemporary Perspectives 53 (Jul/Dez 2007): 001- 160 .

Torres, Sonia, and Eloína Santos, eds. Ilha do Desterro: Literaturas de Língua Inglesa: Mediações Globais/ Literatures in English: Global Mediation 54 (Jan/ Jun 2008): 001-168.

Silveira, Rosane, Barbara O. Baptista, and Rosana Denise Koerich, eds. Ilha do Desterro: English Interphonology Perception, Production and Effect of Instruction 55 (Jul/Dez 2008): 001-218.

Rudy, Susan, and Maria Lúcia Milléo Martins, eds. Ilha do Desterro: Poetics and Other Discourses of Resistance in Canada 56 (Jan/Jun 2009): 001-184.

Wasserman, Renata M., and Sandra Regina Goulart Almeida, eds. Itha do Desterro: On Foreign Land: Ideologies and Travel Discourse 57 (Jul/Dez 2009): 001-176.

Bastos, Beatriz Kopschitz X., and José Roberto O'Shea, eds. Ilha do Desterro: Contemporary Irish Theatre 58 (Jan/Jun 2010): 001-520.

Fernandes, Giséle Manganelli, and Norma Wimmer, eds. Ilha do Desterro: New Perspectives on History Through Literature 59 (Jul/Dez 2010): 001-286.

Mota, Mailce Borges, and Marcia Cristina Zimmer, eds. Ilha do Desterro: Recent Developments in SLA 60 (Jan/Jun 2011): 001-400.

Gatti, José, eds. Ilha do Desterro: South Africa: Literature and Media 61 (Jul/Dez 
2011): 001-376.

Sá, Daniel Serravalle de, and Anelise R. Corseuil, eds. Ilha do Desterro: Gothic: New Directions 62 (Jan/Jun 2012): 001-376.

Tomitch, Lêda M.B., eds. Ilha do Desterro: The neuroscience of Reading 63 (Jul/ Dez 2012): 001-256.

Heberle, Viviane M, and Francisco O. Dourado Veloso, eds. Ilha do Desterro: Studies in multimodality 64 (Jan/Jun 2013): 001-272.

Brandão, Alessandra Soares, and Ramayana Lira de Sousa, eds. Ilha do Desterro: Dis-placed sights/sites: contemporary perspectives on film, media and literature 65 (Jul/Dez 2013): 001-240.

D’Ely, Raquel Carolina Souza Ferras, and Maria da Floria Guará-Tavares, eds. Ilha do Desterro: Second Language learning/teaching and technology 66 (Jan/ Jun 2014): 001-328.

Beck, Magali Sperling, and Rubelise da Cunha, eds. Ilha do Desterro: Crossing North and South: Re-visiting the Americas 67 (Jul/Dez 2014): 001-146.

Dellagnelo, Adriana de Carvalho Kuerten, and Karen E. Johnson, eds. Ilha do Desterro: L2/FL Teacher Education: bridging the complexities of teaching and the learning of teaching 68.1 (Jan/Abr 2015): 001-152.

Campello, Eliane, and Rita Terezinha Schmidt, eds. Ilha do Desterro: Corpo e Literatura/ Body and Literature 68.2 (Mai/Ago 2015): 001-144.

Campello, Edliane, and Rita Terezinha Schmidt, eds. Iha do Desterro: Corpo, Literature, Artes e Mídia/ Body, Literature, Arts and Media 68.3 (Set/Dez 2015): 001-174.

Silveira, Rosane, eds. Ilha do Desterro: The Multiple Facets of Language Studies 69.1 (Jan/Abr 2016): 001-270.

Marques, Eduardo Marks, and Anelise R. Corseuil, eds. Ilha do Desterro: New Cultural Landscapes in Australian Literature and Film 69.2 (Mai/Ago 2016): 001-126.

Bazerman, Charles, and Maria Ester W. Moritz, eds. Ilha do Desterro: Higher Education Writing Studies in Latin America 69.3 (Set/Dez 2016): 001-264.

Beck, Magali Sperling, eds. Ilha do Desterro: Current Critical Perspectives in Literature, Film, and Cultural Studies 70.1 (Jan/Abr 2017): 001-306.

Costa, Claudia de Lima, Ildney de Fátima Souza Cavalcanti, and Joan Haran, eds. Ilha do Desterro: Posthumanism 70.2 (Mai/Ago 2017): 001-128.

Silveira, Rosane, Walcir Cardoso, Ocke-Schwen Bohn, Donesca C. P. Xhafaj, eds. Ilha do Desterro: Investigating Second Language Speech 70.3 (Set/Dez 2017): 001-270.

Notes

1. Dr. Renata Wasserman is the International Editor of Ilha do Desterro, Dr. Anelise R. Corseuil is the Editor-in-Chief of the journal, Dr. Magali Sperling Beck, Dr. Mailce Mota Borges and Dr. Rosane Silveira are Associate Editors of Ilha.

2. "De agora em diante, pretendemos divulgar o pensamento crítico não só em Literatura, mas também em Linguística, Língua e Ensino de Línguas." 


\section{References}

Almeida, Sandra Regina Goulart, ed. Ilha do Desterro: Gender Studies and Feminist Perspectives 42 (Jan/Jun 2002): 001-380.

Ávila, Eliana, and Liane Schneider, eds. Ilha do Desterro: Diversity and/ or Difference? Critical Perspectives 48 (Jan/Jun 2005): 001-248.

Bastos, Beatriz Kopschitz X., and José Roberto O'Shea, eds. Ilha do Desterro: Contemporary Irish Theatre 58 (Jan/Jun 2010): 001-520.

Beck, Magali Sperling, and Rubelise da Cunha, eds. Ilha do Desterro: Crossing North and South: Re-visiting the Americas 67 (Jul/Dez 2014): 001-146.

Beck, Magali Sperling, eds. Ilha do Desterro: Current Critical Perspectives in Literature, Film, and Cultural Studies 70.1 (Jan/Abr 2017): 001-306.

Bellei, Sérgio Luiz Prado, ed. Ilha do Desterro: Trends in Contemporary American Criticism/ Tendências da Crítica Norte-Americana Contemporânea $22\left(2^{\text {nd }}\right.$ Sem 1989): 01-98.

Besner, Neil, and Sérgio Bellei. Ilha do Desterro: Postcolonial Cultures in Contact: Bras(z)il/ Canada(á) 40 (Jan/Jun 2001): 001-159.

Campello, Edliane, and Rita Terezinha Schmidt, eds. Ilha do Desterro: Corpo, Literature, Artes e Mídia/ Body, Literature, Arts and Media 68.3 (Set/Dez 2015): 001-174.

Corseuil, Anelise R., ed. Ilha do Desterro: Film, Literature, and History 32 ( $1^{\text {st }}$ Sem 1997): 001-212.

Corseuil, Anelise R., ed. Ilha do Desterro: Film Beyond Boundaries 51 (Jul/Dez 2006): 001-368.

Costa, Walter Carlos, ed. Ilha do Desterro: Translation/ Tradução 17 (1 $1^{\text {st }}$ Sem 1987): 001-130.

Coulthard, Malcolm, ed. Ilha do Desterro: Discourse Analysis/ Análise do Discurso 11 ( $1^{\text {st }}$ Sem 1984): 001-145.

Coulthard, Malcolm, ed. Ilha do Desterro: Studies in Translation/ Estudos de Tradução 28 ( $2^{\text {nd }}$ Sem 1992): 001-188.

Dellagnelo, Adriana de Carvalho Kuerten, and Karen E. Johnson, eds. Ilha do Desterro: L2/FL Teacher Education: bridging the complexities of teaching and the learning of teaching 68.1 (Jan/Abr 2015): 001-152.

Fernandes, Giséle Manganelli, and Norma Wimmer, eds. Ilha do Desterro: New Perspectives on History Through Literature 59 (Jul/Dez 2010): 001-286.

Funck, Susana Bornéo, ed. Ilha do Desterro: Women Writers/ Mulheres Escritoras 14 ( $2^{\text {nd }}$ Sem 1985): 001-121.

Gatti, José, eds. Ilha do Desterro: South Africa: Literature and Media 61 (Jul/Dez 2011): 001-376.

Marques, Eduardo Marks, and Anelise R. Corseuil, eds. Ilha do Desterro: New Cultural Landscapes in Australian Literature and Film 69.2 (Mai/Ago 2016): 001-126.

Meurer, José L., Keizo Nanri, Makoto Sasaki and Seiko Yasumoto, eds. Ilha do Desterro: Expression, Identity and Society 50 (Jan/Jun 2006): 001-192.

O'Shea, José Roberto, ed. Ilha do Desterro: Accents Now Known: Shakespeare's Drama in Translation 36 (Jan/Jun 1999): 001-404.

O'Shea, José Roberto, Daniela Lapoli Guimarães and Stephan Arnolf Baumgärtel, eds. Ilha do Desterro: Mixed with Other Matter: Shakespeare's Drama Appropriated 49 (Jul/Dez 2005): 001-430. 
Renaux, Sigrid, ed. Iha do Desterro: Canadian Studies 31 (1 $1^{\text {st }}$ Sem 1994): 001-192.

Ristoff, Dilvo I., Fox, Hugh, and Nona Fox, eds. Ilha do Desterro: A Journal of Criticism Centering Around the Invisible Generation 1 (Mar 1979): 01-42.

Ristoff, Dilvo, and Eliane Luz Bayer, eds. Ilha do Desterro 7 (Jul 1982): 001-119.

Rudy, Susan, and Maria Lúcia Milléo Martins, eds. Ilha do Desterro: Poetics and Other Discourses of Resistance in Canada 56 (Jan/Jun 2009): 001-184.

Silveira, Rosane, eds. Ilha do Desterro: The Multiple Facets of Language Studies 69.1 (Jan/Abr 2016): 001-270.

Silveira, Rosane, Walcir Cardoso, Ocke-Schwen Bohn, Donesca C. P. Xhafaj, eds. Itha do Desterro: Investigating Second Language Speech 70.3 (Set/Dez 2017): 001-270.

Torres, Sonia, and Eloína Santos, eds. Itha do Desterro: Literaturas de Lingua Inglesa: Mediações Globais/ Literatures in English: Global Mediation 54 (Jan/Jun 2008): 001-168.

Wasserman, Renata M., and Sandra Regina Goulart Almeida, eds. Itha do Desterro: On Foreign Land: Ideologies and Travel Discourse 57 (Jul/Dez 2009): 001-176. 